\title{
Self-harm - an overview of the tools used to assess non-suicidal self-harming behaviors
}

\author{
Samookaleczanie się - przegląd narzędzi służących \\ do oceny niesamobójczych zachowań samouszkadzających
}

\section{Ewelina Drzał-Fiałkiewcz ${ }^{1}$ ABEF, Agata Makarewicz ${ }^{1}$ AE, Mateusz Walczak ${ }^{1}$ AEF,

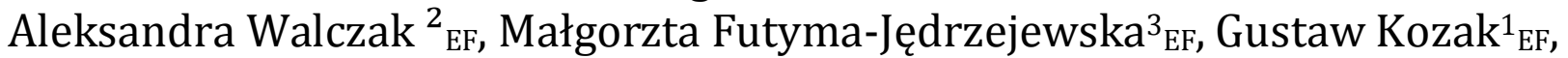 Piotr Frończuk ${ }_{\text {EF, Hanna Karakuła-Juchnowicz }}{ }^{1}$ AE}

\author{
${ }^{1}$ I Department of Psychiatry, Psychotherapy and Early Intervention, Medical University of Lublin \\ ${ }^{2}$ Department of Dermatology, Venereology and Pediatric Dermatology of Autonomous Public University \\ Hospital No. 1 in Lublin \\ ${ }^{3}$ M. Kaczyński Neuropsychiatric Hospital in Lublin \\ ${ }^{4}$ Non-public Healtcare Centre Mental Health Clinic in Biała Podlaska
}

\begin{abstract}
Introduction: Non-Suicidal Self-Injury (NSSI) is the deliberate injury to one's own body intended to cause mental or physical harm to oneself. In view of the growing scale of the NSSI, especially among young people without identifying any other psychiatric disorders, the disorder was included in both DSM-5 and ICD10 as independent diagnostic entity. Many etiopathogenetic hypotheses and research tools assessing various aspects of NSSI have been developed.

The aim of the work is to present and discuss the most commonly used scales for NSSI assessment.

Method: A review of available literature was made using the databases Medline / PubMed, using the key words: "self injury", "selfmutilation", "non- suicidal,", "NSSI", "self-harm" and time descriptors: 2005- 2017

Results: Available tools were divided into three groups: I- scaleof self-assessment made by the patient, II- assessment made by the clinician, and III- auxiliary scale.

Conclusions: None of the available scales covers the complexity of the NSSI phenomenon. For the overall NSSI assessment, seve ral NSSI assessment tools are suggested, taking into account both self-assessment scales and clinical evaluation.
\end{abstract}

Keywords: self-injury, self-mutilation, non-suicidal, NSS, NSSI, self-harm

\section{Streszczenie}

Wstęp:Niesamobójcze samookaleczanie się (NSSI) to umyśle uszkadzanie własnego ciała mające na celu spowodowanie sobie psychicznej albo fizycznej szkody. Wobec narastającej skali zjawiska dokonywania NSS, szczególnieu młodych osób bez stwierdzania innych zaburzeń psychicznych, zaburzenie to zostało wyodrębnione zarówno w DSM-5 jak i ICD10 jako samodzielne jednostki. Stworzono wiele hipotez etiopatogenetycznych oraz narzędzi badawczych oceniających różne aspekty NSSI.

Celem pracy jest przedstawienie i omówienie najczęściej stosowanych skal do oceny NSSI.

Metoda:Dokonano przeglądu dostępnej literatury korzystając z baz Medline/PubMed, używając słów kluczy: „samouszkodzenia”, „,samookaleczenie się,, „nie samobójcze”, „NSS”, „NSSI”, „Self-Injury” oraz deskryptorów czasowych: 2005- 2017.

Wyniki:Dostępne narzędzia podzielono na trzy grupy: I- skale samooceny dokonywanej przez pacjenta, II- oceny dokonywanej przez klinicystę, III-skale pomocnicze.

Wnioski:Żadna z dostępnych skal nie obejmuje złożoności zjawiska NSS. W celu całościowej oceny NSS sugeruje się zastosowanie kilku narzędzi do oceny NSS, uwzględniając zarówno skale samooceny jak i oceny klinicznej.

Słowa kluczowe: szamouszkodzenia, samookaleczanie się, nie samobójcze, NSS, NSSI.

\section{Introduction}

Non-Suicidal Self-Injury (NSSI) is the deliberate injury to one's own body intended to cause mental or physical harm to oneself [1].It can be a symptom of mental disorders or diseases. It occurs when there is a direct self- destruction in which the individual makes harm tohimself/herselfand attacks his/her own body in a voluntary, intentional, direct way and going beyond the norms adopted in a given culture [2]. Currently, the problem of self-injury, especially by young people, is growing expo- 
nentially. The research shows that in the general global population, $4 \%-6 \%$ of adults undertake behaviors related to self-harm [3, 4].The vast majority are adolescents (in this age group as much as $11-39 \%$ engage in self-harm behavior) [5]. In the population of people hospitalized in psychiatric hospitals, as much as $21 \%$ of adults and $40-69 \%$ of adolescents are harming themselves [6]. Probably as much as $10-20 \%$ of secondary and high school students engage in auto-aggression. The majority of patients begin to harm themselves during adolescence (about 12-14 years), however, about $39 \%$ of people engage in the first self-injury behavior only after the age of 17 . Women are making harm to themselves 2-4 times more often than men [6].

In view of the increasing scale of the NSSI phenomenon, this disorder was included both in DSM-5 $[7,8]$ and ICD10 $[9,10]$ as independent diagnostic entity. In the DSM-5 classification published by the American Psychiatric Association in 2013, NSSI was included in the group of non-specific impulse control disorders. Diagnostic criteria that must be met in order to give adiagnosis of NSSI: preoccupation with physical injury to oneself without intentions of suicide and impossibility to stop the impulse. An act of self-mutilation should be preceded by an uncontrollable, growing state of dysphoria, tension, anger and anxiety.The act of auto-aggression is associated with a state of relief, contentment and / or release from the sense of depersonalization. According to DSM-5, such acts must be repeated at least 5 times according to the same pattern. In addition, such a person cannot be affected by psychosis, transsexuality or mental retardation. The last diagnostic criterion concerns the stress caused by NSSI or significantly impairs the functioning of the person [7].

The International Statistical Classification of Diseases and Related Health Problems ICD-10 from 1996 classifies NSSI in group X- External causes of illness and death, including the method of their implementation, e.g. through smoke, fire and flames, using a sharp tool [9].

The literature emphasizes the complexity of NSSI causes [11]. Psychological factors, such as the lack of ability to recognize and express emotions, and the perception of emotions as dangerous and shameful are of great importance $[11,12]$. Self-injuring people often suppress their feelings, are unaware of their needs and do not satisfy them. They also have no sense of their own borders and independence. They often have a negative self-image and they feel aversion to their own body. They experience a sense of strangeness, loneliness [12]. This is often associated with traumatic childhood experiences such as sexual abuse and physical aggression $[11,12]$.Some of self- injuriesare associated with the occurrence of mental illness and the occurrence of psychopathological symptoms, such as hallucinations and delusions (especially guilt and punishment) or with a significantly depressed mood in the course of depression [13]. It also happens that people self-harm themselves under the influence of experiences related to the use of psychoactive substances [14]. Such self-injury can be severe, such as cutting a penis, limb, finger or gouging eyes out[14]. The influence of the media, especially the Internet should not be disregarded[15].Currently, there are more and more websites, blogs and chats related to the subject of auto aggression and suicidal death [15]. It is likely that genetic factors also influence self-injury, but this relationship has not been thoroughly investigated [16]. Environmental factors also play an important role in the development of NSSI [17]. They occur especially in groups in which the sensation of pain and contempt for it ennobles, for example, practiced in some youth circles and prisons of the so-called selfharm scars [17].There are also known religious and ritual practices, during which people are harmed, for example, by initiation rituals practiced in many African and Central American tribes or for status in the Roman Empire, Egypt or Japan [17].At present, the phenomena that until recently were not widespread in European culture and were considered as self-harm, have been enjoying increasing popularity and gradually increasing social acceptance. The fact that they have become a cultural phenomenon means that by a large proportion of researchers they are no longer considered to be self-harm [18]. This refers to the bodymodifications, which sometimes can significantly interpose in the human body [19]. Currently the most commonly seen bodymodification is piercing, but tattoos and scarification are also becoming more and more popular, which are created by cutting, scratching, chilblaining or burning the skin [19]. Less common, but more and more common are implants or foreign body implanted in the body, giving a 3D effect by changing the shape of the arm, leg or head [19].

Interest has been aroused by the hypothesis of behavioral addiction, in which self-harms cause the release of opioid compounds in the brain, constituting an "internal reward" $[20,21]$. The proof of the relevance of this theory is the concentration of self-injured people on autoaggression, the organization of time and thoughts of the individual around autoaggression [18], the lower level of $\beta$-endorphin and met-enkephalin in the cerebrospinal fluid in the NSSI group compared to the control group 
[20], and attempts to treat self-mutilating people with Naltrexone, an opioid receptor antagonist [22].

The aim of the work is to present and elucidate the most commonly used scales for NSSI assessment.

\section{Method}

A review of available literature using Medline/Pubmed and Google Scholar databases, using the key words: "self-injury", "self-mutilation", "non-suicidal", "NSS", "NSSI", "self-harm" and time descriptors: 2005- 2017.

\section{Results}

The problem of non-suicidal self-harming behavior is a topic of interest for many researchers and clinicians. There are more and more questionnaires to assess NSSI, but it should be noted that each tool has a different scope and examines self-mutilation at a different angle.The questionnaires that directly assess autoaggressive behavior include: ABASI (Alexian Brothers Assessment of SelfInjury) [23], ISAS (Statements About Self-Injury) [24], SIT (Self-Injury Trauma Scale) [25] ] and NSSI-AT (The NonSuicidal Self-Injury Assessment Tool) [26]. Each of the presented tools gives the therapist a different point of view on the acts performed. The SIT scale examines the risk of self-injury in the future. On the ABASI scale, questions only concern the last 12 months and the type of selfinjury and situations related to the moment before the act was made. ISAS, on the other hand, defines the behaviors and functions that the act of self-harming means for the patient. The NSSI-AT questionnaire is the longest and most extensive questionnaire that comprehensively examines many issues related to self-harming acts.

In addition, when testing NSSI patients, other tools may be used that do not directly examine self-harm but provide additional information on other aspects of patient functioning. DERS Questionnaire (Difficulties in Emotion Regulation Scale) [27] is used to assess the patient's difficulties in regulating emotions. SBQ-R (The Suicide Behaviors Questionnaire) [29] may indicate to the clinician a potential risk of suicide by a patient who performs selfmutilation. The ABUSI scale (Alexian Brothers Urge to the Self-Injury Scale) [23] provides data on thoughts and impulses for self-harm.

Some of the surveys used for examining people with self-injuries have been designed in such a way that the patients could answer the questions themselves (selfreport questionnaire). These are questionnaires such as: ABASI, ABUSI, ISAS, DERS, SBQ-R, NSSI-AT. Some of the questionnaires are intended for a doctor who completes the questionnaire after a thorough examination of the patient, both psychiatric and physical. An example of such a scale is SIT.

In order to achieve the transparency of the work, the discussed research tools are divided into the following groups:

1. Self-evaluation scales of a patient involved in NSSI disorder

1.1 Alexian Brothers Assessment of Self-Injury (ABASI)[23]

1.2 Inventory of Statements About Self-Injury(ISAS) [24]

1.3 The Non-Suicidal Self-Injury Assessment Tool (NSSI-AT)[26]

1.4 Deliberate Self-Harm Inventory (DSHI) [28]

1.5 Self-Harm Inventory (SHI) [30]

1.6 Self-Harm Behavior Questionnaire (SHBQ) [31]

1.7 The Ottawa Self-Injury Inventory (OSI) [32]

1.8 Functional Assessment of Self-Mutilation (FASM)

2. Clinical scales with the evaluation made by the clinician 2.1 Self-Injury Trauma Scale (SITS)[25]

2.2 Motivational Assessment Scale (MAS) [34]

2.3 Behavior Problems Inventory (BPI)[25]

2.4 Overt Aggression Scale (OAS) [25]

2.5 Self-Injurious Behavior Questionnaire (SIBQ) [25]

2.6 Suicide Attempt and Self-Injury Interview (SASII) [35]

2.7 Self-Injurious Thoughts and Behaviors Interview (SITB) [36]

3. Ancillary scales in the assessment of persons involved in NSSI disorder

3.1 Alexian Brothers Urge to Self-Injury Scale (ABUSI)[23]

3.2 Difficulties in Emotion Regulation Scale (DERS)[27]

3.3 The Suicide Behaviors Questionnaire - Revised (SBQ-R)[29]

3.4 Self-Injury Self-Report Inventory (SISRI) [37]

3.5 SuicideAssessmentChecklist (SAC) [38]

\section{Self-evaluation scales of a patient involved in NSSI disorder}

1.1 Alexian Brothers Assessment of Self-Injury (ABASI)[23] is a self-report questionnaire made by patients who are involved in self-harm activities and simultaneously don't show any suicidal thoughts and tendencies. The questionnaire does not investigate unintentional and suicidal attempts. Questions refer to previous year, or 12 months in the life of the patient. The questionnaire is divided into several parts. 
The first part of the survey is related to the types of self-injury. The patient's task is to determine the number of days in the year in which self-injury was made, how many times during the day and at what age the patient began self-harm in this way. The patient answers three of the above questions in the context of: cutting the skin that caused bleeding or weeping; scratches, abrasions of the skin, bumps followed by a rush or bleeding; scorching oneself; making tattoos or piercing to feel pain; deliberate choking or limiting the access to air; pulling hair, eyebrows, eyelashes to self-harm or cause pain; dropping blood; inserting objects into / under the skin; hitting oneself; hitting something with your head or any limb; interfering healing of injuries or wounds; causing falls from stairs resulting in injury or causing pain; carvingof words, shapes, patterns, etc. in the skin to damage or hurt oneself; deliberate breaking of limbs; picking in the eyes, ears or other parts of the body; getting into a fight to experience an injury or to hurt oneself; consume / swallow items to mutilate or hurt oneself; getting excited about self-harm or pain; limiting food, vomiting or using laxatives to self-harm or cause pain; risky sexual behavior to mutilate or hurt oneself; failure to comply with medical recommendations or deliberate deterioration of one's health.

The questions in the next part of the questionnaire relate to the situations preceding the self-injury. The patient is to assess the frequency with which he/she experienced specific feelings, thoughts and actions that occurred immediately before the act of self-aggression: negative feelings or thoughts ("distress", anger, sadness, anxiety, tension, critical thoughts); difficulties in interpersonal contacts; a strong need or even a desire to selfharm; thoughts about self-harming; self-mutilation before someone else could hurt the patient; before, during and after the self-injury act performing of rituals, which were connected with self-mutilation; drinking of alcohol and using drugs; limiting of food, vomiting or using laxatives to influence the appearance or weight.

In this part of the ABASI questionnaire, the patient chooses for each of the above questions whether such situations happened "never", "sometimes", "from time to time", "usually" or "often".

The next part of the questionnaire is structured so as to get answers from the subject about the benefits of self-mutilation. It contains questions about patient selfknowledge on the subject: predictions that making selfharm will bring him/her a feeling of relief from negative feelings and thoughts; opportunities to focus or solve interpersonal problems; strengthening positive emotions (joy, pleasure, gratitude, etc.). In addition, it defines the patient's attitude to the acts of self-harming in the following questions: is self-injury a problem for the patient; would the patient like to stop self-harming or reduce the number of acts carried out; does the patient feel unreal in the course of self-harm; when self harm is not made, does the patient feel more resignation experiences or suicidal thoughts or feelings.The patient determines for each of the above statements whether he/she "strongly agrees", "agrees", "has no opinion", "disagrees", "strongly disagrees" with them.

The last part of the questionnaire is about the patients' past. The respondents determine whether they suffered sexual, physical, emotional or verbal violence in the past and whether they had ever attempted suicide. In addition, they determine the places on the body that they subjected to self-harm and whether they were subjected to therapy because of self-injury, how many times and in which centers.

The ABASI scale is a popular scale used in many studies and publications, including "Assessing DSM-5 nonsuicidal self-injury disorder in a clinical sample" [23] and "The DSM-5 diagnosis of non-suicidal self-injury disorder: review of the empirical literature" [39].

1.2. Another questionnaire on self-assessment is the Inventory of Statements About Self-Injury (ISAS) [29]. This questionnaire examines the functions of self-harming and the frequency of 12 behaviors associated with it.It consists of two main parts.

The first part contains open questions about the nature of auto-aggressive behaviors and the role of selfharm. The patient is asked to provide the number of selfharms done so far, broken down by the way it has been done (cutting self, biting self, burning self, pinching self, pulling hair, scratching self, hitting self, abrading self of the skin, stinging self, swallowing dangerous substances ). The next point concerns the description of the main way in which the patient performs self-mutilation acts.

The second part of the questionnaire contains 39 closed questions, in which the patient chooses one answer from: "no relevance", "little relevance", " some relationship". Based on the analysis of the answers to these questions, conclusions can be drawn as to the function of selfmutilation in the patient's life.One can determine whether self-mutilation is aimed at: mood regulation, setting boundaries, punishing oneself, giving an excuse to take care of themselves, avoiding dissociation, avoiding suicide, searching for feelings, triggering reactions in others, 
checkingone's endurance as a sign of stress, revenge, showing autonomy. The last two questions are open and optional. The first one is: "Write a list of statements that more suits you than those mentioned above."The second is: "Write a list of statements that should be added to the table above, even if they do not apply to you."

ISAS is characterized by good psychometric values [40] and is one of the popular tools used in both scientific research [41, 42, 44] and everyday practice [39].

1.3 The Non-Suicidal Self-Injury Assessment Tool (NSSI-AT) [44] is the longest, most-developed tool that comprehensively investigates many issues related to selfmutilation. The questions contained in it concern the characteristics of self-injury, the functions of these acts for the patient, the frequency of self-mutilation, the age when the first episode took place, the location of scars and fresh injuries, internal motivation to make such an act, severity of wounds, habits related to the acts, habits and observations of self-injury relationships with situations from the patient's everyday life, revealing the acts to the environment, therapeutic experiences, personal reflection and possibly environmental advice on self-harming [45].

The process of designing and psychometric properties of NNSI-AT have been described in detail in the following papers: "Validity and Reliability of the NonSuicidal Self-Injury Assessment Tool (NSSI-AT): Why Use the NSSI-AT?" [45], "Assessment of non-suicidal selfinjury: Development and initial validation of the NonSuicidal Self-Injury-Assessment Tool (NSSI-AT) "[44] and" DSM-5 diagnosis of the empirical literature "[39].

1.4 Deliberate Self-Harm Inventory (DSHI) [28] is another scale that can be used to study self-harming subjects. The questions contained herein concern only selfharm. It was created on the assumption that self-injury is a deliberate, direct destruction of body tissues without suicidal thoughts [46]. This scale assesses the frequency, severity, duration and types of behavior of self-inflicted persons. This survey consists of 17 elements and is based on self-description. DSHI is a very reliable tool for assessing both self-injury as well as past suicidal behavior.

DSHI has been used in many studies, among others: "Risk factors for deliberate self-harm among female students: The role and interaction of childhood maltreatment, emotional inexpressivity, and affect intensity/ reactivity"[47],"Targeting emotion dysregulation in the treatment of self-injury" [48], "The role of emotional responding and childhood maltreatment in the development and maintenance of deliberate self-harm among male undergraduates" [49].
1.5. Self-Harm Inventory (SHI) [30] is another scale investigating the level of self-destructiveness in patients who perform self-mutilation. It was created as a screening test for diagnosing people with borderline personality disorder [50]. This inventory was created taking into account the definition of self-injury, according to which self-injury is the direct destruction of body tissue without a conscious intention to commit suicide, resulting in tissue damage. It evaluates the frequency, severity, duration and type of behavior associated with self-mutilation [50]. The SHI also contains questions about suicide attempts and forms of direct self-destructiveness [51].

1.6 Self-Harm Behavior Questionnaire (SHBQ) [31] is a scale that examines the level of selfdestructiveness not only at the level of self-injury, but also includes questions about thoughts, gestures and suicide attempts [51]. The questionnaire is divided into 4 parts. Part A asks about intentional self-harm that the individual did not identify as suicidal in nature, Part B asks about suicide attempts, Part $\mathrm{C}$ asks about suicide threats, and Part D about suicide ideation. Questions grouped in four sections examine the full range of non-self-harming suicide behaviors. If we treat self-destructive behavior as a predictor of suicidal behavior, this scale could be helpful in diagnosing future thoughts and behaviors that can lead to death [31].

1.7 The Ottawa Self-Injury Inventory (OSI) [32] is a questionnaire that examines the occurrence, frequency, self-harming functions, and dependence on psychoactive substances in the context of self-harm. The patient answers questions by choosing one of the options from 0 never to 4 - daily / always. The self-injury function is examined by 31 items on the OSI scale, by 7 items - the dependence on psychoactive substances. The frequency of self-injuries is examined by the question: "How often have you injured yourself in the last 6 months of your life without intending to kill yourself?".

The self-report questionnaire was used in many studies, e.g. The Ottawa Self-Injury Inventory: Evaluation of an assessment measure of non-suicidal self-injury in an inpatient sample of adolescents [52] and Psychometric Properties of the Functions and Addictive Features Scales of the Ottawa Self-Injury Inventory: A Preliminary Investigation Using a University Sample [53].

1.8 Functional Assessment of Self-Mutilation (FASM) [33]. Functions measured by FASM include avoidance (e.g. using self-harm to avoid school, work or other activities), reducing tension (e.g. using selfmutilation to relieve the feeling of numbness or emptiness), 
external reinforcement (e.g. using self-harm to attract attention) , and self-stimulation (e.g. using self-destructive behaviors to be like somebody respected) [53].

The psychometric properties of FASM are presented in Psychometric Properties of the Functions and Addictive Features Scales of the Ottawa Self-Injury Inventory: A Preliminary Investigation Using a University Sample [54], and the very scale has been used in a paper entitled"A Functional Approach to the Assessment of Self-Mutilative Behavior"[55].

\section{Clinical scales of assessment carried out by the clinician:}

2.1. Self-Injury Trauma Scale (SIT) [56]. This is one of the first tools that measures the level of self-harm [50]. It is filled in by a doctor after thorough examination of the patient both physically and taking an accurate psychiatric history. This tool measures the topography of self-injury, the type of damage and the degree of tissue damage [51]. The questionnaire consists of three parts. The first describes the traces/scars of self-mutilation acts.The site of their occurrence is assessed (around the head or face, the presence of injuries on other parts of the body, scratching, picking, rubbing skin, eye gouging, biting, ingestion of inedible materials, vomiting or rumination,air swallowing, or hair pulling) . In the second part, the measurement of the surface trauma is described. The number, type and severity of injuries and their character in all parts of the body are determined.The part three is a scoring summary in which the number index and the severity index of self-injury are calculated together with the estimation of the current risk of repeating behaviors related to self-injury (low, medium or high).

The SIT scale is a tool used in many scientific studies [57].

2.2 Motivational Assessment Scale (MAS) [34] measures motivation to self-harm. It is intended for people with mental disorders and mentally handicapped. Assessment using this tool is done by a nurse, family member or teacher. It measures the patient's motivations perceived by the observer, not the self-injured person [51].

2.3 Behavior Problems Inventory (BPI) [25] is intended for people with disabilities and mental disorders. It is a tool in which not only auto aggressive behaviors are measured; 14 items in the inventory concern self-injury, 24 stereotypical behaviors, and 11- aggressive behaviors [51].

BPI was used, among others, in a study conducted by Carminati et al. [58], which observed a decrease in the frequency and severity of self-harming behaviors in people with ASD taking venlafaxine compared to the placebo control group.
2.4 Overt Aggression Scale (OAS) [25], similar to BPI, measures not only tissue damage. In addition to the estimated measurement of self-injury, this tool is used to examine verbal and physical aggression towards oneself and others, as well as objects [51].

The OAS scale has been used, among others, in a study conducted by Benedetti et al. [59]. The above experiment analyzed the effect of deep brain stimulation (DBS) of the posterior hypomegalangular area of the hypothalamus on the incidence of convulsions in patients with drug-resistant epilepsy (DRE), associated with intractable aggressive behavior (IAB). Based on the AOS score, there was found a clear improvement after the procedure relative to the condition from before the operation, taking into account such criteria as the risk of self-injury and the risk of damage to objects or other people.

\subsection{Self-injurious Behavior Questionnaire (SIBQ)}

[25] is another tool for assessmentmade by an observer. It is used not only to measure the frequency and degree of trauma, but also to assess the type of measures used by caregivers to reduce auto-aggressive behaviors. Antisocial and stereotypical behaviors as well as sleep disorders, problems with concentration, emotions and mood, are also assessed [51].

\section{6. Suicide Attempt and Self-Injury Interview} (SASII) [35] is a questionnaire that evaluates suicidal tendencies (4 questions), willingness to get help (2 elements), the presence of an earlier message about the will to commit suicide ( 2 questions) and lethality (3 questions). The questionnaire excluded the presence of a farewell letter and the impulsiveness of the episode, due to the inclusion of these phenomena in questions about the desire to get help.Since both elements reflect important aspects of suicide attempts that are of clinical and research relevance, both items remain as single questions to which the patient answers during the interview. SASII, contains 6 screening questions, 9 open-ended questions to provide information for interviewer coding and 22 items measuring the time and frequency of self-inflicted acts, methods used and lethality of the method, both for declared suicide attempts and non-suicidal attempts. The above items also contain questions about communicating intentions of suicide before the episode, impulsiveness and prediction of the probability of being rescued, mental health status and the treatment process.The interviewer receives one of six -scale scores and assesses the relationship between the risk of death and the possibility of rescuing the patient. Interviewers categorize each episode as one of six scores: 1) non-suicidal self-injury, 2) an ambiva- 
lent suicide attempt, 3) a nonambivalent suicide attempt or 4) failed suicide.

\subsection{Self-Injurious Thoughts and Behaviors Inter-}

view (SITB) [36]. This structured interview contains 169 items grouped in 5 modules. This questionnaire examines: a) suicidalideation("Have you ever had thoughts of killing yourself?"), (b) suicide plans ("Have you ever made a plan to kill yourself?"), (c) suicide gestures ("Have you ever done something to let others believe you wanted to kill yourself when you really had no intention of doing so?"), (d) suicide attempts ("Have you ever made an actual attempt to kill yourself in which you had at least some intent to die? ") and (e) non-suicidal self-injury ("Have you ever done something to purposely hurt yourself without intending to die? ").

\section{Scales useful in the study of people engaged in self- harm:}

3.1 The next scale of the Alexian Brothers, which is used for self-assessment of people who are engaged in self-injury is: Alexian Brothers Urge is a Self-Injury Scale (ABUSI) [23]. Questions relate to the thoughts and impulses associated with self-harm that the patient had the week before. The questionnaire consists of five questions.The first is: how often do you think about hurting yourself or how would you like to do it. The patient selects one of seven responses: "never," "rarely" (1-2 times in the last week), "occasionally" (3-4 times during the last week), "sometimes" (5-10 times in the past week or 1-2 times a day), "often" (11-20 times in the last week or 2-3 times a day), "most of the time" (20-40 times in the last week or 3 - 6 times a day), "almost all the time" (more than 40 times in the last week or more than 6 times a day).The second question relates to self-harm done the week before. The patient chooses one of the answers: "not at all", "small, very gentle impulse", "gentle impulse", "moderate impulse", "strong impulse, but easily controlled", "strong impulse, but controlled with difficulty", "a strong impulse that would lead to self-injury if it were possible".The next question assesses the patient's temporary involvement in thinking about self-injury or choosing its form. Another question that the patient is responding to is: "How difficult was it to resist the temptation of selfharming last week?". The subject may choose one of seven answers: from "I did not have any difficulties" to "there was no way to resist the temptation of self-harm." In the last question, the patient is asked to summarize his/her previous answers.The subject chooses one of seven answers: "I never think about self-harming, nor have I ever had the will to self-harm myself", "I rarely think about self-injury and the desire to self-injury", "I rarely think about self-harming and willingness to self-harm," "sometimes I have thoughts of doing self-harm and willingness to self-harm," "I often think about self-harming and willingness to self-harm" "most of the time I have thoughts about self-harming and most of the time I have the desire to do it", "thinking about doing self-injury is practically all the time and the willingness to do self-injury is practically all the time."

This questionnaire has been categorized as a tool to distinguish self-injury that is unrelated to suicidal thoughts from those associated with the desire to die [60]. ABUSI has been used in many studies, including the "Emotional and Behavioral Effects of an Online Study of Non-suicidal Self-Injury: An Experimental Analysis" [62] as a complement to the range of research tools.

3.2 Difficulties in Emotion Regulation Scale (DERS) [27] is another self-reporting scale of selfassessment performed by the patient. It consists of 36 closed questions about experienced emotions. The patient determines how often these conditions occur: almost never $-0-10 \%$, sometimes - $11-35 \%$, about half of the time - 36-65\%, most of the time - 66-90\%, almost always $67-100 \%$. Then the researcher analyzes the questionnaire, the score and divides the answers given to questions into 6 groups: unacceptable emotional response, problems focusing on the target, problems in impulse control, lack of emotional awareness, limited access to emotional control strategies, lack of emotional clarification.

This measure is a popular research tool. It was used, among others, in the work "Multidimensional Assessment of Emotion Regulation Difficulties in Adolescents Using the Difficulties in Emotion Regulation Scale" [62], as well as in "Borderline personality disorder features," "Emotion dysregulation and non-suicidal self-injury": in a sample of community-dwelling Italian adolescents "[63]. It has been described in Maria Zetterqvist's article "The DSM-5 diagnosis of the empirical literature" [39].

3.3 The Suicide Behaviors Questionnaire - Revised (SBQ-R) [29] is a questionnaire that does not directly examine self-injury, only a tendency to commit suicide. It is an auxiliary questionnaire that can be used to investigate whether self-harming tendencies are also associated with suicidal tendencies. This is a questionnaire containing 4 questions: "Have you ever thought about killing yourself?", "How often did you think about suicide?", "Have you ever told someone that you are going to commit suicide?", "Is it likely that will you commit suicide in the future? "The patient has to choose one

answer for each question. Each answer is scored differently. Points sum up and assess the risk of suicide.

3.4 Self-Injury Self Report Inventory (SISRI) [37] is a scale that can be used as an aid to self-injury testing, such as eating disorders, dependence on SPA or PTSD. It was created to investigate the phenomenon of autoaggressive behaviors, which may manifest in self-injury, but also in indirect forms of autoaggression. There are questions about suicide attempts [51]. 
Table 1, developed by Kubiak [51] presents the scope of the studies of various aspects of NSSI at selected scales was compared (published with authors permission).

\begin{tabular}{|c|c|c|c|c|c|c|c|c|c|c|c|c|}
\hline \multirow[b]{2}{*}{ Methods } & \multicolumn{7}{|c|}{$\begin{array}{l}\text { The scope of the construct defini- } \\
\text { tion }\end{array}$} & \multicolumn{5}{|c|}{ Goals and application } \\
\hline & $\begin{array}{l}\mathscr{0} \\
\frac{\pi}{2} \\
\frac{\pi}{\pi} \\
\stackrel{0}{\Xi} \\
\tilde{n}\end{array}$ & 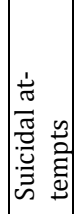 & 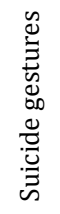 & 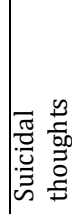 & 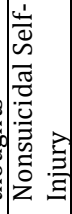 & 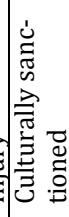 & 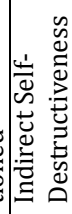 & 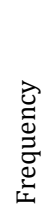 & 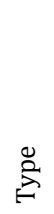 & $\begin{array}{l}\vec{E} \\
\vec{D} \\
\stackrel{\vec{D}}{\infty} \\
\infty\end{array}$ & $\begin{array}{l}\mathscr{2} \\
\tilde{0} \\
\tilde{y} \\
\tilde{\Xi} \\
\simeq\end{array}$ & 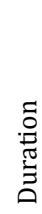 \\
\hline Self-Injury Self-Report Inventory (SISRI) (Juzwin 2004) & & + & & & + & & + & + & + & + & + & + \\
\hline Deliberate Self-Harm Inventory (DSHI) (Gratz 2001) & & & & & + & & & + & + & + & & + \\
\hline $\begin{array}{l}\text { Self-Injurious Thought and Behavior Interview (SITBI) } \\
\text { (Nock, Holmberg, Photos I Michel 2007) }\end{array}$ & + & + & + & + & + & & & + & + & + & + & + \\
\hline Inventory Statements About Self-Injury (ISAS) (Klonsky I Glenn 2008) & & & & & + & & & + & + & & + & \\
\hline Self-Injury Motivation Scale II (SIMS) (Osuch, Noll I Putman 1999) & & + & & & + & & & & & & + & \\
\hline Functional Assesment of Self-Mutilation (FASM) (Lloyd, Kelly, Hope 1997) & & & & & + & & & + & + & & + & + \\
\hline Self-Harm Behavior Questionaire (SHBQ) (Guttierez, Osman, Barrios, Kopper 2001) & & + & + & + & + & & & + & & + & & \\
\hline Ottawa Self-Injury Inventory (OSI) (Nixon i Cloutier 2002) & & + & & + & + & & & + & + & & + & \\
\hline Self-Harm Inventory (SHI) (Sansone, Wiederman, Sansone 1998) & & + & & & + & & + & & & & & \\
\hline Self-Injurious Behavior Questionaire (SIB-Q) (Schroeder, Rojhan, Reese 1997) & & & & & + & & & & & & & \\
\hline $\begin{array}{l}\text { Suicide Attempt Self-Injury Interview (SASII) } \\
\text { (Lineman, Comtois, Brown, Heard, Wagner 2006) }\end{array}$ & & + & + & + & + & & & + & & + & + & \\
\hline $\begin{array}{l}\text { Self-Harm Survey (SHS) I Motivations Underlying Self-Harm Questionaire } \\
\text { (HUSHQ) Laye-Guidhn I Schonert-Reicht 2005) }\end{array}$ & & + & & + & + & & + & + & & & + & \\
\hline Self-Injury Questionaire (SIQ) (Alexander 1999) & & & & & + & + & + & + & + & & + & \\
\hline Self-Injury Inventory (SII) (Zlotnicki, Shea, Pearlstein, Simpson, Costello, Begin 1996) & & & & & + & & + & + & + & & & + \\
\hline Self-Injury Questionaire (SIQ) (Vanderlindeni, Vandereycken 1997) & & & & & + & & + & & & & & \\
\hline
\end{tabular}

Table 2 presents the scope of the studies of various aspects of NSSI at selected scales was compared (prepared by authors of this article).

\begin{tabular}{|c|c|c|c|c|c|c|c|c|c|c|c|c|}
\hline \multirow[b]{2}{*}{ Methods } & \multicolumn{7}{|c|}{ The scope of the construct definition } & \multicolumn{5}{|c|}{$\begin{array}{l}\text { Goals and applica- } \\
\text { tion }\end{array}$} \\
\hline & $\begin{array}{l}\frac{n}{\pi} \\
\frac{\pi}{2} \\
\frac{\pi}{0} \\
\stackrel{⿹}{\Xi} \\
\omega\end{array}$ & 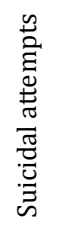 & 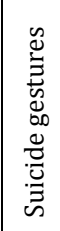 & 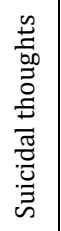 & 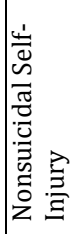 & 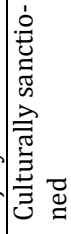 & 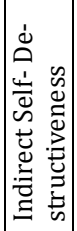 & 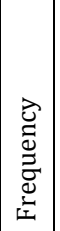 & $\stackrel{\stackrel{2}{2}}{\Leftrightarrow}$ & $\begin{array}{l}\vec{D} \\
\vec{D} \\
\vec{D} \\
\stackrel{D}{n}\end{array}$ & 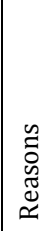 & 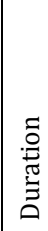 \\
\hline Alexian Brothers Assesment of Self Injury (ABASI) [23] & & & & & + & & + & + & + & & + & \\
\hline The Non-Suicidal Self-Injury Assessment Tool (NSSI-AT) [26] & & & & & + & & & + & + & + & + & + \\
\hline Self-Injury Trauma Scale (SITS) [25] & & & & & + & & & & + & + & & \\
\hline Motivational Assessment Scale (MAS) [34] & & & & & + & & & & & & + & \\
\hline Behawior Problems Inventory (BPI) [25] & & & & & + & & + & & & & & \\
\hline Overt Aggression Scale (OAS) [25] & & & & & + & & + & & & + & & \\
\hline Self-Injurious Thoughts and Behaviors Interview (SITB) [36] & + & + & + & + & + & & & & & & & \\
\hline Alexian Brothers Urge to Self-Injury Scale (ABUSI) [23] & & & & & + & & & + & & & & + \\
\hline Difficulties in Emotion Regulation Scale (DERS) [27] & & & & & & & & & & & + & \\
\hline The Suicide Behaviors Questionnaire - Rvised (SBQ-R) [29] & & & & + & & & & & & & & \\
\hline Suicide Assesment Checklist (SAC [38] & & & & & & & & & & & + & \\
\hline
\end{tabular}

3.5 Suicide Assessment Checklist (SAC) [38] is a tool that is designed to assess the loss of rational thinking, lack of social support, possibly the presence of depression, SPA abuse, or parental negligence [51].

The scope of issues related to NSSI assessed using various available research tools is presented in two com- plementary tables: tab. 1 by Kubiak [51] and tab. 2 prepared by the authors of this article (containing scales not included in table 1).

\section{CONCLUSIONS:}

Non- suicidal self-injury is not a phenomenon observed only among patients of hospitals and psychiatric 
clinics. In the environment more and more often there are met auto aggressive people never psychiatrically treated, who cannot cope in other ways with increasing internal tension. The scale of the phenomenon may be evidenced by the World Awareness Day of Auto aggression set up on 1 March [64]. The increase in the number of NSSI cases in society is certainly influenced by environmental factors, although they do not fully explain the scale of the problem. The NSSI of young people is growing rapidly. The therapy of this type of disorder is comprehensive, taking into account the prevailing reasons for its occurrence. To be able to effectively help, a multidimensional assessment of non-suicidal self-injury is needed. Each of the tools presented in this article provides different information about the patients, their behavior, type of self-injury, emotional adjustment skills, etc. In order to be able to comprehensively assess NSSI and accompanying disorders, it is necessary to use a complementary scale, because none of the available scales includes the complexity of NSSI.

może być dotknięta psychozą, transseksualizmem czy upośledzeniem umysłowym. Ostatnie kryterium diagnostyczne dotyczy stresu wywoływanego przez NSSI lub znacząco zakłóca funkcjonowanie osoby [7].

Międzynarodowa Statystyczna Klasyfikacja Chorób i Problemów Zdrowotnych ICD-10 z 1996 roku klasyfikuje NSSI w grupie X- Zewnętrznych przyczyny zachorowania i zgonu, uwzględniając metodę ich dokonania, np. przez dym, ogień i płomienie, przy użyciu narzędzia ostrego [9].

W literaturze podkreśla złożoność przyczyn NSSI [11]. Ogromne znaczenie mają czynniki psychologiczne, takie jak brak umiejętności rozpoznawania i wyrażania emocji oraz postrzeganie emocji jako niebezpiecznych i wstydliwych $[11,12]$. Osoby dokonujące samouszkodzeń często tłumią swoje uczucia, nie mają świadomości swoich potrzeb i nie zaspokajają ich. Nie mają również poczucia własnych granic oraz niezależności. Często mają negatywny obraz siebie oraz odczuwają niechęć od własnego ciała. Przeżywają poczucie obcości, samotności [12]. Często jest to związane $\mathrm{z}$ traumatycznymi przeżyciami $\mathrm{z}$ dzieciństwa, takimi jak nadużycia seksualne i agresja fizyczna [11, 12]. Część samouszkodzeń wiąże się z występowaniem chorób psychicznych i występowaniem objawów psychopatologicznymi, takich jak halucynacje i urojenia (szczególnie winy i kary) lub ze znacznie obniżonym nastrojem w przebiegu depresji [13]. Zdarza się również, że osoby dokonują samouszkodzeń pod wpływem przeżyć związanych z zażywaniem substancji psychoaktywnych [14]. Takie samookaleczenia bywają znaczne, jak np. obcięcie członka, kończyny, palca lub wyłupanie oczu [14]. Nie należy również zapominać o wpływie mediów, a szczególnie Internetu [15]. Aktualnie powstaje coraz więcej stron Internetowych, blogów i chatów związanych $\mathrm{z}$ tematyką autoagresji i śmierci samobójczej [15]. Prawdopodobnie wpływ na to, czy dana osoba będzie dokonywała samouszkodzeń mają również czynniki genetyczne, ale zależność ta nie została dokładnie zbadana [16].Ogromną role w rozwoju NSSI odgrywają także czynniki środ owiskowe [17] Zdarzają się szczególnie w grupach, w których odczuwanie bólu i pogarda dla niego nobilituje, np. praktykowane w niektórych 
środowiskach młodzieżowych i więzieniach tzw. sznyty [17]. Znane są również praktyki religijne i rytualne, podczas których osoby biorące w nich udział okaleczają się $\mathrm{np}$. rytuały inicjacyjne praktykowane $\mathrm{w}$ wielu plemionach afrykańskich i Ameryki Środkowej lub dla oznaczenie statusu w Imperium Rzymskim, Egipcie czy Japonii [17]. Aktualnie na całym świecie coraz większą popularnością i stopniowo wzrastającą akceptacją społeczną cieszą się zjawiska, które do niedawna nie były rozpowszechnione w kulturze europejskiej i były uważane za samookaleczenia. Fakt, że stają się zjawiskiem kulturowym powoduje, że przez dużą część badaczy nie są już uznawane za samookaleczenia [18]. Mowa tutaj o bodymodyfikacjach, które czasem mogą znacznie ingerować w ludzkie ciało [19]. Aktualnie najczęściej spotykaną bodymodyfikacja jest piercing, ale coraz większą popularnością cieszą się również tatuaże czy skaryfikacje, które powstają poprzez nacinanie, wycinanie, zadrapywanie, odmrażanie lub wypalanie skóry [19]. Mniej popularne, choć coraz częściej spotykane są implanty, czyli ciała obce wszczepiane do organizmu nadając efekt 3D zmieniając kształt ręki, nogi czy głowy [19].

Zainteresowanie budzi hipoteza uzależnienia behawioralnego, w której samookaleczenia powodują wyzwolenie w mózgu związków opioidowych, stanowiących „wewnętrzna nagrodę" [20, 21]. Dowodem słuszności tej teorii ma być koncentracja osób samookaleczających się na aktach autoagresji, organizacja czasu i myśli jednostki wokół autoagresji [18], niższy poziom $\beta$-endorphin i metenkephalin w plynie mózgowo-rdzeniowym w grupie NSSI w porównaniu z grupą kontrolną [20], oraz podejmowane próby leczenia osób samouszkadzających się za pomocą Naltrexonu, antagonisty receptorów opioidowych [22].

Celem pracy jest przedstawienie i omówienie najczęściej stosowanych skal do oceny NSSI.

Metoda: Dokonano przeglądu dostępnej literatury korzystając z baz Medline i Google scholar, używając słów kluczy: „samouszkodzenia”, „samookaleczenie się”, „nie samobójcze”, „NSS”, „NSSI”, „Self-Injury” oraz deskryptorów czasowych: 2005- 2017.

\section{Wyniki:}

Problem niesamobójczych zachowań samouszkadzających jest tematem zainteresowań wielu badaczy oraz klinicystów. Powstaje coraz więcej kwestionariuszy służących ocenie zjawiska NSSI, jednak należy zauważyć, iż każde $\mathrm{z}$ narzędzi ma inny zakres i bada samookaleczenia pod innym kątem. Do kwestionariuszy, które w sposób bezpośredni oceniają zachowania autoagresywne należą np.: ABASI (Alexian Brothers Assessment of Self-Injury) [23], ISAS (Statements About SelfInjury) [24], SIT (Self-Injury Trauma Scale) [25] i NSSI-AT
(The Non-Suicidal Self-Injury Assessment Tool) [26]. Każde z przedstawionych narzędzi daje terapeucie inny punkt spojrzenia na dokonywane akty. Skala SIT bada ryzyko popełnienia samouszkodzeń w przyszłości. W skali ABASI pytania dotyczą jedynie ostatnich 12 miesięcy oraz rodzaju samouszkodzeń i sytuacji związanych z chwilą przed dokonaniem aktu. Natomiast ISAS określa zachowania i funkcje, jakie akt samookaleczania pełni dla pacjenta. Kwestionariusz NSSI-AT jest ankietą najdłuższą i najbardziej rozbudowaną, która kompleksowo bada wiele zagadnień związanych z aktami samouszkadzania się.

Dodatkowo, badając pacjentów z NSSI, można stosować inne narzędzia, które nie badają bezpośrednio samookaleczania, ale dają dodatkowe informacje na temat innych aspektów funkcjonowania pacjenta. Kwestionariusz DERS (Difficulties in Emotion Regulation Scale) [27] służy do oceny trudności pacjenta w regulacji emocji. SBQ-R (The Suicide Behaviors Questionnaire) [29] może wskazać klinicyście potencjalne ryzyko popełnienia samobójstwa przez pacjenta, który dokonuje aktów samouszkadzania się. Skala ABUSI (Alexian Brothers Urge to Self-Injury Scale) [23] dostarcza danych na temat myśli i impulsów do samouszkadzania się.

Część ankiet stosowanych do badania osób z samouszkodzeniami została skonstruowana tak, by pacjent mógł odpowiedzieć na pytania samodzielnie. Są to kwestionariusze takie jak: ABASI, ABUSI, ISAS, DERS, SBQR, NSSI-AT. Część kwestionariuszy jest przeznaczona dla lekarza, który wypełnia ankietę po dokładnym zbadaniu pacjenta, zarówno psychiatrycznym jak i fizykalnym. Przykładem takiej skali jest SIT.

Celem uzyskania przejrzystości pracy, omawiane narzędzia badawcze podzielono na następujące grupy:

\section{Skale samooceny pacjenta dokonującego NSSI}

1.1 Alexian Brothers Assessment of Self-Injury (ABASI) [23]

1.2 Inventory of Statements About Self-Injury (ISAS) [24]

1.3 The Non-Suicidal Self-Injury Assessment Tool (NSSI-AT) [26]

1.4 Deliberate Self-Harm Inventory (DSHI) [28]

1.5 Self-Harm Inventory (SHI) [30]

1.6 Self-Harm Behavior Questionnaire (SHBQ) [31]

1.7 The Ottawa Self-Injury Inventory (OSI) [32]

1.8 Functional Assessment of Self-Mutilation (FASM) [33]

2. Skale kliniczne z oceną dokonywaną przez klinicystę

2.1 Self-Injury Trauma Scale (SITS) [25]

2.2 Motivational Assessment Scale (MAS)[34]

2.3 Behavior Problems Inventory (BPI) [25]

2.4 Overt Aggression Scale (OAS) [25]

2.5 Self-Injurious Behavior Questionnaire (SIBQ) [25]

2.6 Suicide Attempt and Self-Injury Interview (SASII) [35] 
2.7 Self-Injurious Thoughts and Behaviors Interview (SITB) [36]

3. Skale pomocnicze w ocenie osób dokonujących NSSI

3.1 Alexian Brothers Urge to Self-Injury Scale (ABUSI)- Skala Braci Abasi szacująca myśli i chęć samouszkodzenia się [23]

3.2 Difficulties in Emotion Regulation Scale (DERS) [27]

3.3 The Suicide Behaviors Questionnaire - Revised (SBQ-R) [29]

3.4 Self-Injury Self-Report Inventory (SISRI) [37]

3.5 Suicide Assessment Checklist (SAC) [38]

\section{Skale samooceny pacjenta dokonującego sa- mouszkodzeń:}

1.1 Alexian Brothers Assessment of Self-Injury (ABASI) - Kwestionariusz Braci Alexian dla oceny samouszkodzeń [23] jest kwestionariuszem samooceny dokonywanej przez pacjentów, którzy dokonują samouszkodzeń ciała i jednocześnie nie mają myśli ani tendencji samobójczych. Kwestionariusz nie bada zdarzeń nieumyślnych oraz prób samobójczych. Pytania dotyczą ostatniego roku, czyli 12 miesiecy z życia pacjenta. Kwestionariusz jest podzielony na kilka części.

Pierwsza część ankiety związana jest z rodzajami samouszkodzeń. Pacjent ma za zadanie określić liczbę dni w roku, w których dokonywał samouszkodzeń, ile razy w ciągu dnia dokonywał takich aktów oraz w jakim był wieku, gdy zaczął się samouszkadzać w ten sposób. Na trzy powyższe pytania pacjent odpowiada w kontekście: nacinania skóry, które powodowało u niego krwawienie lub płacz; zadrapań, otarć skóry, uderzeń takich, po których widać podbiegnięcie krwawe lub krwawienie; przypalania siebie; wykonywania tatuaży lub kolczykowania w celu sprawienia sobie bólu; naumyślnego zakrztuszania się lub ograniczania sobie dostępu do powietrza; pociągania się za włosy, brwi, rzęsy, by dokonać samouszkodzenia lub sprawić sobie ból; upuszczania sobie krwi; wstawiania sobie obiektów w/pod skórę; bicia się; uderzania w coś głową lub jakąkolwiek z kończyn; utrudniania gojenia się urazów lub ran; powodowania upadków ze schodów, by sprawić sobie uraz lub spowodować ból; wykrawania w skórze słów, kształtów, wzorów, itd., by uszkodzić się, lub sprawić sobie ból; naumyślnego łamania sobie kończyn; dłubania w oczach, uszach lub innych częściach ciała; wdawania się w bójki, by doświadczyć urazu lub by sprawić sobie ból; spożywania/połykania przedmiotów, by skrzywdzić się lub sprawić sobie ból; ekscytowania się samouszkodzeniami lub sprawianiem sobie bólu; ograniczania sobie jedzenia, wymiotowania lub używania środków przeczyszczających, by dokonać samouszkodzenia lub sprawić sobie ból; ryzykownych zachowań seksualnych, by skrzywdzić siebie lub sprawić sobie ból; nie stosowania się do zaleceń medycznych lub celowego pogarszania swojego stanu zdrowia.

Pytania w kolejnej części ankiety dotyczą sytuacji poprzedzających dokonanie samouszkodzenia. Pacjent ma ocenić częstość z jaką doznawał określonych uczuć, myśli i czynów, które miały miejsce bezpośrednio przed aktem autoagresji: negatywnych uczuć lub myśli („distress”, złość, smutek, niepokój, napięcie, krytyczne myśli); trudności w kontaktach interpersonalnych; silnej potrzeby lub wręcz popędu, by dokonać samouszkodzenia; myśli o samouszkodzeniu się; dokonywał samouszkodzenia, zanim ktoś inny mógłby go zranić; przed, w trakcie i po akcie odbywał rytuały, które miały związek z dokonywanym samookaleczeniem się; stosował alkohol i narkotyki; ograniczał swoje jedzenie, wymiotował lub stosował środki przeczyszczające, by wpłynąć na swój wygląd lub wagę. W tej części kwestionariusza ABASI pacjent dla każdego z powyższych pytań dokonuje wyboru, czy takie sytuacje występowały: „nigdy”, „czasem”, „od czasu do czasu”, „zazwyczaj”, czy „często”.

Kolejna część testu jest skonstruowana tak, by uzyskać odpowiedzi od osoby badanej na temat jakie korzyści uzyskuje poprzez samouszkadzanie się. Zawiera pytania dotyczące samowiedzy pacjenta na tematy: przewidywań, że dokonanie samouszkodzenia się przyniesie mu uczucie ulgi od negatywnych uczuć i myśli; możliwości skoncentrowania się lub rozwiązania problemów interpersonalnych; wzmacniania pozytywnych emocji (radości, przyjemności, wdzięczności itd.). Dodatkowo określa stosunek pacjenta do dokonywanych aktów samouszkadzania się w pytaniach: czy samouszkodzenie jest dla pacjenta problemem; czy chciałby przestać samouszkadzać się lub zmniejszyć liczbę dokonywanych aktów; czy czuje odrealnienie $\mathrm{w}$ trakcie samouszkadzania się; czy kiedy nie dokonuje samouszkodzeń, doznaje więcej myśli lub uczuć rezygnacyjnych lub samobójczych. Pacjent dla każdego z powyższych twierdzeń określa, czy „zdecydowanie zgadza się”, „zgadza się”, „nie ma zdania”, „nie zgadza się”, „zdecydowanie nie zgadza się" z nimi.

Ostatnia część kwestionariusza dotyczy przeszłości pacjenta. Badany określa, czy w przeszłości doznał aktów przemocy seksualnej, fizycznej, emocjonalnej lub werbalnej oraz czy kiedykolwiek podejmował próbę samobójczą. Ponadto określa miejsca na ciele, które poddawał samookaleczeniom oraz czy był poddawany terapii z powodu dokonywania samookaleczeń, ile razy oraz w jakich ośrodkach.

Skala ABASI jest popularną skalą wykorzystywaną $\mathrm{w}$ wielu badaniach i publikacjach m.in. w „Assessing DSM5 nonsuicidal self-injury disorder in a clinical sample" [23] oraz „The DSM-5 diagnosis of nonsuicidal self-injury disorder: review of the empirical literature" [39]. 
1.2. Kolejnym kwestionariuszem samooceny jest Inventory of Statements About Self-Injury (ISAS) [29] Kwestionariusz ten bada funkcje samouszkadzania się oraz częstość 12 zachowań z tym związanych. Składa się z dwóch głównych części.

Pierwsza część zawiera pytania otwarte dotyczące charakteru zachowań autoagresywnych i funkcji, jakie pełni samookaleczanie się. Pacjent proszony jest o podanie liczby samouszkodzeń dokonanych w ciągu dotychczasowego życia z podziałem na sposoby, w jaki zostały wykonane (cięcie, gryzienie się, przypalanie, krojenie, szczypanie, ciągnięcie za włosy, drapanie, uderzanie, tarcie skóry, kłucie się, połykanie niebezpiecznych substancji). Kolejny punkt dotyczy opisu głównego sposobu, w jaki pacjent dokonuje aktów samouszkadzania się. Kolejne pytania odnoszą się do wieku pacjenta przy dokonywaniu pierwszego aktu samookaleczenia się oraz okresu ostatnio dokonanego samouszkodzenia się. Następne trzy pytania są pytaniami zamkniętymi. Pacjent zaznacza jedną z odpowiedzi „tak”, „czasem” lub „nie” jako odpowiedź na pytania: „czy doświadczasz bólu fizycznego podczas aktów samookaleczania się”, „,zy jesteś sam, gdy dokonujesz aktów samookaleczania się”, „czy chcesz zaprzestać samoouszkodzeń". W ostatnim pytaniu pacjent określa, ile czasu upływa od wystąpienia myśli, by dokonać samouszkodzenia, aż do chwili, gdy pacjent dokonuje aktu samookaleczenia się.

Druga część ankiety zawiera 39 pytań zamkniętych, w których pacjent wybiera jedną odpowiedź spośród: „bez związku”, „ma niewielki związek”, „jest związek”. Na podstawie analizy odpowiedzi na te pytania można wyciągnąć wnioski co do funkcji jaką pełnią akty samookaleczania w życiu pacjenta. Można określić, czy akty samookaleczania mają na celu: regulację nastroju, wyznaczanie granic, karanie siebie, dają pretekst do zaopiekowania się sobą, uniknięcie dysocjacji, uniknięcie samobójstwa, poszukiwanie odczuwania, wywołanie reakcji u innych, sprawdzenie swojej wytrzymałości jako oznaka stresu, zemstę, okazanie autonomii. Ostatnie dwa pytania są otwarte i opcjonalne. Pierwsze, brzmi: „Wypisz listę stwierdzeń, które bardziej do Ciebie pasują niż te wymienione wyżej”. Drugie, to: „Napisz listę stwierdzeń, które powinny być dodane do tabeli wyżej, nawet jeśli nie dotyczą Ciebie".

ISAS charakteryzuje się dobrymi wartościami psychometrycznymi [40] i należy do popularnych narzędzi wykorzystywanych zarówno $\mathrm{w}$ badaniach naukowych [41, 42, 44], jak i codziennej praktyce [39].

1.3 The Non-Suicidal Self-Injury Assessment Tool (NSSI-AT) [44] jest narzędziem najdłuższym, najbardziej rozbudowanym, który kompleksowo bada wiele zagadnień związanych z aktami samookaleczania się. Pytania w niej zawarte dotyczą charakterystyki samouszkodzeń, funkcji tych aktów dla pacjenta, częstości dokonywania samookaleczeń, wieku pierwszego epizodu, lokalizacji blizn i świeżych zranień, wewnętrznej motywacji do dokonania takiego aktu, dotkliwości zranień, zwyczajów związanych $\mathrm{z}$ dokonywanymi aktami, przyzwyczajeń i obserwacji związków samouszkodzeń z sytuacjami z życia codziennego pacjenta, ujawniania aktów przed otoczeniem, doświadczeń z terapii, osobistej refleksji i ew. porad otoczenia na temat samouszkadzania się [45].

Proces powstawani oraz własnosci psychometryczne NNSI-AT zostały dokladnie opisane w kolejnych pracach: "Validity and Reliability of the Non-Suicidal Self-Injury Assessment Tool (NSSI-AT): Why Use the NSSI-AT?" [45], "Assessment of nonsuicidal selfinjury: Development and initial validation of the NonSuicidal Self-Injury-Assessment Tool (NSSI-AT)" [44] oraz "DSM-5 diagnosis of nonsuicidal self-injury disorder: review of the empirical literature" [39].

1.4 Deliberate Self-Harm Inventory (DSHI) [28] to kolejna skala, którą można używać do badania osób samoouszkadzających się. Pytania w niej zawarte dotyczą jedynie samoranienia się. Powstała przy założeniu, że samookaleczenie jest celowym, bezpośrednim niszczeniem tkanek ciała bez myśli samobójczych [46]. Skala ta ocenia częstotliwość, dotkliwość, czas trwania oraz rodzaje zachowań osób dokonujących samookaleczenia. Ankieta ta składa się $\quad \mathrm{z} \quad 17$ elementów i bazuje na samoopisie. DSHI jest bardzo wiarygodnym narzędziem dla oceny zarówno samookaleczeń, jak również przeszłych zachowań samobójczych.

DSHI została wykorzystana w wielu badaniach $\mathrm{m}$. in.: "Risk factors for deliberate self-harm among female college students: The role and interaction of childhood maltreatment, emotional inexpressivity, and affect intensity/ reactivity" [47], "Targeting emotion dysregulation in the treatment of selfinjury" [48], "The role of emotional responding and childhood maltreatment in the development and maintenance of deliberate self-harm among male undergraduates" [49].

1.5 Self-Harm Inventory (SHI) [30] to kolejna skala badająca poziom autodestruktywności u pacjentów dokonujących aktów samookaleczania się. Powstała jako badanie przesiewowe dla diagnozowania osób z zaburzeniem osobowości typu borderline [50]. Inwentarz ten powstał biorąc pod uwagę definicję samookaleczeń, według której samouszkodzenie to bezpośrednie zniszczenie tkanki ciała bez świadomego zamiaru samobójczego, skutkujace uszkodzeniem tkanki. Ocenia częstotliwość, dotkliwość, czas trwania oraz rodzaj zachowań związanych z dokonywaniem samookaleczeń [50]. W SHI zawarte są również pytania dotyczące prób samobójczych oraz form autodestruktywności bezpośredniej [51]. 
1.6 Self-Harm Behavior Questionnaire (SHBQ)

[31] to skala, która bada poziom autodestruktywności nie tylko na poziomie samoranienia, ale również zawiera pytania o myśli, gesty i próby samobójcze [51]. Ankieta jest podzielona na 4 części. Część A dotyczy wykonywanych umyślnie samozranień o charakterze nie samobójczym. Część B dotyczy prób samobójczych. Część C dotyczy kierowania gróźb samobójczych. Pytania zawarte $\mathrm{w}$ części D dotyczą wyobrażeń na temat samobójstwa. Pytania zgrupowane w czterech sekcjach badają pełny zakres nie samobójczych zachowań samouszkadzających się. Jeśli traktujemy niesamobójcze zachowania autoagresywne jako predyktor ew. zachowań samobójczych, to skala ta mogłaby być pomocna przy diagnizowaniu ew. przyszłych myśli i zachowań, które mogą prowadzić do śmierci [31].

1.7 The Ottawa Self-Injury Inventory (OSI) [32] to kwestionariusz, który bada występowanie, częstość, funkcje samookaleczania się oraz zależność od substancji psychoaktywnych w kontekście samozranień. Pacjent na pytania odpowiada wybierając jedną z możliwości od 0 nigdy do 4 - codziennie/zawsze. Funkcję samouszkodzeń bada 31 pozycji w skali OSI, 7 zależność od substancji psychoaktywnych. Częstość samozranień jest badana pytaniem: „Jak często w ciągu ostatnich 6 mc zraniłeś/aś się bez intencji zabicia się?".

Kwestionariusz wykorzystany został $\mathrm{w}$ wielu badaniach $\mathrm{m}$. in., np. w The Ottawa Self-Injury Inventory: Evaluation of an assessment measure of nonsuicidal selfinjury in an inpatient sample of adolescents [52] oraz w Psychometric Properties of the Functions and Addictive Features Scales of the Ottawa Self-Injury Inventory: A Preliminary Investigation Using a University Sample [53].

1.8 Functional Assessment of Self-Mutilation (FASM) [33]. Funkcje mierzone przez FASM obejmują ucieczkę (np. używanie samozranienia w celu uniknięcia szkoły, pracy lub innych czynności), redukcję napięcia (np. użycie samookaleczenia w celu złagodzenia poczucia zdrętwienia lub pustki), wzmocnienie zewnętrzne (np. użycie samouszkodzenia w celu zwrócenia uwagi), i samostymulacja (np. używanie zachowań autodestruktywnych do bycia jak ktoś szanowany) [53].

Własnosci psychometryczne FASM zostały przedstawione $\mathrm{w}$ Psychometric Properties of the Functions and Addictive Features Scales of the Ottawa Self-Injury Inventory: A Preliminary Investigation Using a University Sample [54], a sama skala zostala zastosowana m.in. w pracy A Functional Approach to the Assessment of Self-Mutilative Behavior [55].

2. Skale kliniczne $\mathrm{z}$ oceną dokonywaną przez klinicystę:

2.1. Self-Injury Trauma Scale (SIT) [56] To jedno z pierwszych narzędzi, które mierzy poziom autodestruktywności [50]. Jest uzupełniana przez lekarza po dokład- nym zbadaniu pacjenta zarówno fizykalnym, jak i zebraniu dokładnego wywiadu psychiatrycznego. Za pomocą tego narzędzia dokonuje się pomiaru topografii samouszkodzeń, typu uszkodzeń oraz stopnia uszkodzenia tkanki [51]. Kwestionariusz składa się z trzech części. W pierwszej opisuje się ślady po samouszkodzeniach. Ocenia się miejsce ich występowania (okolice głowy lub twarzy, obecność śladów na innych częściach ciała, czy są to zadrapania, skubanie, otarcia, gryzienie, dłubanie w oczach, czy pacjent spożywa materiały niejadalne, czy wymiotuje lub połyka powietrze, czy wyrywa sobie włosy). W drugiej opisywany jest pomiar powierzchni poddanej samookaleczeniu. Określana jest liczba i dotkliwość zranień oraz ich charakter we wszystkich okolicach ciała. Trzecia część to podsumowanie, w którym wylicza się indeks liczby i indeks dotkliwości samouszkodzeń wraz z oszacowaniem aktualnego ryzyka powtórzenia zachowań związanych z samouszkodzeniami (niskie, średnie lub wysokie).

Skala SIT jest narzędziem wykorzystywanym $\mathrm{w}$ wielu badaniach naukowych [57].

2.2 Motivational Assesment Scale (MAS) [34] mierzy motywację do dokonania samozranienia. Przeznaczona jest dla osób z zaburzeniami psychicznymi oraz upośledzonych umysłowo. Ocena przy pomocy tego narzędzia dokonywana jest przez, pielęgniarkę, członka rodziny lub nauczyciela. Mierzy motywacje pacjenta postrzeganą przez obserwatora, a nie samą osobę dokonującą samookaleczenia się [51].

2.3 Behavior Problems Inventory (BPI) [25] jest przeznaczona dla osób upośledzonych oraz z zaburzeniami psychicznymi. Jest narzędziem, w którym pomiarowi podlegają nie tylko zachowania autoagresywne. 14 pozycji w inwentarzu dotyczy samouszkodzeń, 24 zachowań stereotypowych, a 11 zachowań agresywnych [51].

BPI wykorzystano m. in. w badaniu przeprowadzonym przez Carminati i wsp. [58] , w którym obserwowano spadek częstości i nasilenia zachowań samookaleczających u osób z ASD przyjmujących wenlafaksynę w porównaniu do grupy kontrolnej placebo.

2.4 Overt Aggression Scale (OAS) [25] podobnie jak w BPI, mierzy nie tylko uszkodzenie tkanek. Poza szacunkowym pomiarem samouszkodzeń, narzędzie to służy do badania agresji werbalnej i fizycznej w stosunku do siebie oraz innych, jak również przedmiotów [51].

Skala OAS znalazła zastosowanie m.in w badaniu przeprowadzonym przez Benedetti i wsp. [59]. W powyższym doświadczeniu analizowano wpływ głębokiej stymulacji mózgu (ang. DBS, deep brain stimulation) tylnoprzyśrodkowej okolicy podwzgórza na częstość występowania drgawek u pacjentów z lekooporną padaczką (ang. DRE, drug-resistant epilepsy), związaną z ciężkimi, agresywnymi zachowaniami (ang. IAB, intractable aggressive 
behaviour). Na podstawie oceny wg skali AOS wykazano wyraźną poprawę po zabiegu względem stanu sprzed operacji, uwzględniając takie kryteria jak ryzyko samouszkodzeń oraz ryzyko uszkodzenia przedmiotów bądź innych osób.

2.5 Self-Injurious Behavior Questionnaire (SIBQ) [25] to kolejne narzędzie oceny dokonywanej przez obserwatora. Stosuje się je nie tylko do pomiaru częstości oraz stopnia uszkodzeń, ale również ocenia się rodzaj środków stosowanych przez opiekunów w celu ograniczenia zachowań autoagresywnych. Dokonuje się również oceny zachowań antyspołecznych i stereotypowych oraz zaburzeń snu, problemów z koncentracją uwagi, emocjami oraz nastrojem [51].

2.6 Suicide Attempt and Self-Injury Interview (SASII) [35] to kwestionariusz, który służy o oceny tendencji samobójczych (4 pytania), chęć uzyskania pomocy (2 elementy), obecność wcześniejszego komunikatu o chęci popełnienia samobójstwa (2 pytania) i śmiertelność ( 3 pytania). Z kwestionariusza zostały wykluczone obecność listu pożegnalnego oraz impulsywność epizodu, z powodu umieszczenia tych zjawisk w pytaniach o chęć uzyskania pomocy. Ponieważ oba elementy odzwierciedlają ważne aspekty prób samobójczych, które mają znaczenie kliniczne i badawcze, obie pozycje pozostały jako pojedyncze pytania, na które pacjent udziela odpowiedzi podczas wywiadu. SASII, zawierającą 6 pytań przesiewowych, 9 pytań otwartych w celu dostarczenia informacji do kodowania ankieterów oraz 22 pozycje mierzące czas i częstotliwość aktów samookaleczenia, stosowane metody i śmiertelność metody, zarówno przy deklarowanych próbach samobójczych, jak i nie samobójczych. Powyższe pozycje zawierają również pytania o komunikowanie intencji samobójczych przed epizodem, impulsywność i przewidywanie prawdopodobieństwa bycia ocalonym, stan zdrowia psychicznego oraz proces leczniczy. Dokonujący analizy otrzymuje jeden z sześciu wyników skali oraz ocenia stosunek między ryzykiem śmierci, a możliwością uratowania pacjenta. Badający kategoryzują każdy epizod jako jeden z sześciu wyników: 1) nieposłuszne samookaleczenie, 2) ambiwalentna próba samobójcza, 3) nieuzasadniona próba samobójcza lub 4) nieudane samobójstwo.

2.7 Self-Injurious Thoughts and Behaviors Interview (SITB) [36]. Skala ta zawiera 169 punktów zgrupowanych w 5 modułach. Kwestionariusz ten bada: a) myśli samobójcze ("Czy kiedykolwiek miałeś myśli o zabiciu siebie?"), (b) plany samobójcze ("Czy kiedykolwiek rzeczywiście planowałeś się zabić?"), (c) gesty samobójcze ("Czy kiedykolwiek zrobiłeś coś, aby inni wierzyli, że chciałeś się zabić, kiedy naprawdę nie miałeś zamiaru tego zrobić? "), (d) próby samobójcze ("Czy kiedykolwiek podjąłeś próbę zabicia siebie, w której miałeś zamiar umrzeć? ") i (e) niesamobójcze samookaleczenia ("Czy kiedykolwiek zrobiłeś coś, aby celowo zranić siebie bez zamiaru śmierci?").

III. Skale pomocne w badaniu osób dokonujących samouszkodzeń:

3.1 Kolejna skala Braci Alexian, która służy do samooceny osób dokonujących samookaleczania się to: Alexian Brothers Urge to Self-Injury Scale (ABUSI) [23] Pytania dotyczą myśli oraz impulsów związanych z samouszkadzaniem się, które pacjent miewał w ciągu ostatniego tygodnia. Kwestionariusz składa się z pięciu pytań. Pierwsze brzmi: jak często zdarzają Ci się myśli o krzywdzeniu siebie lub o tym, w jaki sposób chciałbyś to zrobić. Pacjent wybiera jedną z siedmiu odpowiedzi: "nigdy”, „rzadko” (1-2 razy w ciągu ostatniego tygodnia), "okazjonalnie" (3-4 razy w ciągu ostatniego tygodnia), "czasami" (5-10 razy w ciągu ostatniego tygodnia lub 1-2 razy w ciągu dnia), „często” (11-20 razy w ciągu ostatniego tygodnia lub 2-3 razy w ciągu dnia), „przez większość czasu" (20-40 razy w ciągu ostatniego tygodnia lub 3-6 razy w ciągu dnia), „blisko cały czas” (więcej niż 40 razy w ciągu ostatniego tygodnia lub więcej niż 6 razy w ciągu dnia). Drugie pytanie dotyczy: samouszkodzenia się $\mathrm{w}$ ciągu ostatniego tygodnia. Pacjent wybiera jedną z odpowiedzi: „w ogóle nie było”, „niewielka, bardzo łagodny impuls”, „łagodny impuls”, „umiarkowany impuls”, „silny impuls, ale z łatwością kontrolowany”, „silny impuls, ale kontrolowany z trudem”, „silny impuls, który doprowadziłby do samouszkodzenia się, gdyby była taka możliwość". Kolejne pytanie ocenia czasowe zaangażowanie pacjenta w rozmyślanie o samouszkodzeniu się lub wyborze jego formy. Kolejne pytanie, na które odpowiada badany pacjent brzmi: „Jak trudno było oprzeć się pokusie samouszkadzania się w ciągu ostatniego tygodnia?”. Badany może wybrać jedną z siedmiu odpowiedzi: od „nie miałem żadnych trudności” do „nie było możliwości, by oprzeć się pokusie samouszkodzenia się". W ostatnim pytaniu pacjent proszony jest o dokonanie podsumowania swoich wcześniejszych odpowiedzi. Osoba badana wybiera jedną spośród siedmiu odpowiedzi: „nigdy nie zdarzają mi się myśli o dokonywaniu samouszkodzenia się, ani nigdy nie miałem chęci, by dokonać samouszkodzenia się”, „,bardzo rzadko miewam myśli o dokonywaniu samouszkodzenia się i chęć, by dokonać samouszkodzenia się", „rzadko miewam myśli o dokonywaniu samouszkodzenia się i chęć, by dokonać samouszkodzenia się”, „czasami miewam myśli o dokonywaniu samouszkodzenia się i chęć, by dokonać samouszkodzenia się”, „często miewam myśli o dokonywaniu samouszkodzenia się i chęć, by dokonać samouszkodzenia się”, „przez większość czasu mam myśli o tym, by dokonać samouszkodzenia się i przez większość czasu mam chęć, by tego dokonać”, „myśli o dokonaniu samouszkodzenia się są praktycznie cały czas i chęć, by dokonać samouszkodzenia jest praktycznie cały czas".

Kwestionariusz ten został skategoryzowany jako narzędzie do odróżnienia samouszkodzeń, które nie mają związku z myślami samobójczymi od takich, które są 
związane z pragnieniem śmierci [60]. ABUSI został wykorzystany $\mathrm{w}$ wielu badaniach, m.in $\mathrm{w}$ „Emotional and Behavioral Effects of Participating in an Online Study of Nonsuicidal Self-Injury: An Experimental Analysis" [62] jako uzupełnienie gamy narzędzi badawczych.

3.2 Difficulties in Emotion Regulation Scale (DERS) [27] jest kolejną skalą samooceny dokonywanej przez pacjenta. Składa się z 36. pytań zamkniętych dotyczących przeżywanych emocji. Pacjent określa procentowo jak często te stany mają miejsce: prawie nigdy - 0-10\%, czasami - 1135\%, około połowy czasu - 36-65\%, przez większość czasu $66-90 \%$, prawie zawsze - 67-100\%. Następnie badający analizuje ankietę, podlicza punkty i dzieli uzyskane odpowiedzi na pytania na 6 grup: nieakceptowania swojej odpowiedzi emocjonalnej, problemów w skupianiu się na celu, problemów w kontroli impulsów, brak uważności emocjonalnej, ograniczonego dostępu do strategii regulacji emocjonalnej, braku klaryfikacji emocjonalnej.

Skala ta jest popularnym narzędziem badawczym, zastosowana została m. in. w pracach "Multidimensional Assessment of Emotion Regulation Difficulties in Adolescents Using the Difficulties in Emotion Regulation Scale" [62], jak również $w$ "Borderline personality disorder features, emotion dysregulation and non-suicidal selfinjury: Preliminary findings in a sample of communitydwelling Italian adolescents" [63]. Została opisana w artykule Marii Zetterqvist „The DSM-5 diagnosis of nonsuicidal self-injury disorder: review of the empirical literature" [39].

3.3 The Suicide Behaviors Questionnaire - Revised (SBQ-R) [29] jest kwestionariuszem, która nie bada bezpośrednio samouszkodzeń, tylko tendencję do popełnienia samobójstwa. Jest kwestionariuszem pomocniczym, który można wykorzystać do zbadania, czy tendencje do samouszkodzeń wiążą się również z tendencjami samobójczymi. Jest to ankieta zawierająca 4 pytania: „Czy kiedykolwiek myślałeś o tym, by się zabić?”, „Jak często myślałeś, o popełnieniu samobójstwa?”, „Czy kiedykolwiek mówiłeś komuś, że zamierzasz popełnić samobójstwo?”, „Czy jest prawdopodobne, że popełnisz samobójstwo w przyszłości?”. Pacjent ma wybrać po jednej odpowiedzi do każdego pytania. Każda z odpowiedzi jest inaczej punktowana. Punkty się sumuje i ocenia ryzyko popełnienia samobójstwa.

3.4 Self-Injury Self Report Inventory (SISRI) [37] to skala, którą można stosować pomocniczo podczas badania samouszkodzeń, tak jak zaburzeń odżywiania, zależności od SPA czy w PTSD. Została ona stworzona by badać zjawisko zachowań autoagresywnych, które mogą przejawiać się $\mathrm{W}$ samookaleczaniu się, ale również w pośrednich formach autoagresji. Znajdują się tu pytania dotyczące prób samobójczych [51].

3.5 Suicide Assesment Checklist (SAC) [38] to narzędzie, które ma za zadanie ocenić utratę myślenia racjonalnego, brak wsparcia społecznego, ew. obecność depresji, nadużywania SPA, ew. zaniedbania rodzicielskie [51].

Tabela 1. Zakres definicji konstruktu w poszczególnych kwestionariuszach oraz ich cele i zastosowanie (autorstwa Kubiak [51]).

\begin{tabular}{|c|c|c|c|c|c|c|c|c|c|c|c|c|}
\hline \multirow[b]{2}{*}{ Narzędzie badawcze } & \multicolumn{6}{|c|}{ Zakres definicji konstruktu } & \multicolumn{6}{|c|}{$\begin{array}{l}\text { Cele } \\
\text { i zastosowanie }\end{array}$} \\
\hline & 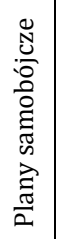 & 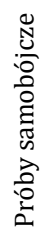 & 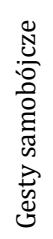 & 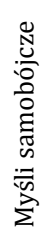 & 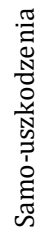 & 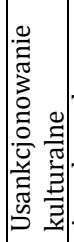 & 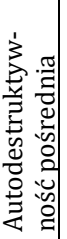 & 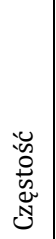 & $\begin{array}{l}0 \\
\pi \\
\frac{\pi}{0} \\
0 \\
01\end{array}$ & 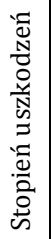 & $\begin{array}{l}3 \\
0 \\
0 \\
3 \\
0 \\
0\end{array}$ & 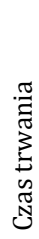 \\
\hline Self-Injury Self-Report Inventory (SISRI) (Juzwin 2004) & & + & & & + & & + & + & + & + & + & + \\
\hline Deliberate Self-Harm Inventory (DSHI) (Gratz 2001) & & & & & + & & & + & + & + & & + \\
\hline $\begin{array}{l}\text { Self-Injurious Thought and Behavior Interview (SITBI) } \\
\text { (Nock, Holmberg, Photos I Michel 2007) }\end{array}$ & + & + & + & + & + & & & + & + & + & + & + \\
\hline Inventory Statements About Self-Injury (ISAS) (Klonsky I Glenn 2008) & & & & & + & & & + & + & & + & \\
\hline Self-Injury Motivation Scale II (SIMS) (Osuch, Noll I Putman 1999) & & + & & & + & & & & & & + & \\
\hline Functional Assesment of Self-Mutilation (FASM) (Lloyd, Kelly, Hope 1997) & & & & & + & & & + & + & & + & + \\
\hline Self-Harm Behavior Questionaire (SHBQ) (Guttierez, Osman, Barrios, Kopper 2001) & & + & + & + & + & & & + & & + & & \\
\hline Ottawa Self-Injury Inventory (OSI) (Nixon i Cloutier 2002) & & + & & + & + & & & + & + & & + & \\
\hline Self-Harm Inventory (SHI) (Sansone, Wiederman, Sansone 1998) & & + & & & + & & + & & & & & \\
\hline Self-Injurious Behavior Questionaire (SIB-Q) (Schroeder, Rojhan, Reese 1997) & & & & & + & & & & & & & \\
\hline $\begin{array}{l}\text { Suicide Attempt Self-Injury Interview (SASII) } \\
\text { (Lineman, Comtois, Brown, Heard, Wagner 2006) }\end{array}$ & & + & + & + & + & & & + & & + & + & \\
\hline $\begin{array}{l}\text { Self-Harm Survey (SHS) I Motivations Underlying Self-Harm Questionaire } \\
\text { (HUSHQ) Laye-Guidhn I Schonert-Reicht 2005) }\end{array}$ & & + & & + & + & & + & + & & & + & \\
\hline Self-Injury Questionaire (SIQ) (Alexander 1999) & & & & & + & + & + & + & + & & + & \\
\hline Self-Injury Inventory (SII) (Zlotnicki, Shea, Pearlstein, Simpson, Costello, Begin 1996) & & & & & + & & + & + & + & & & + \\
\hline Self-Injury Questionaire (SIQ) (Vanderlindeni, Vandereycken 1997) & & & & & + & & + & & & & & \\
\hline
\end{tabular}


Tabela 2. Zakres definicji konstruktu w poszczególnych kwestionariuszach oraz ich cele i zastosowanie (poszerzony o skale zawarte w artykule, a nie znajdujące się w Tabeli 1 (autorstwa własnego)

\begin{tabular}{|c|c|c|c|c|c|c|c|c|c|c|c|c|}
\hline \multirow[b]{2}{*}{ Narzędzie badawcze } & \multicolumn{7}{|c|}{ Zakres definicji konstruktu } & \multicolumn{5}{|c|}{ Cele i zastosowanie } \\
\hline & 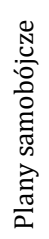 & 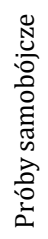 & 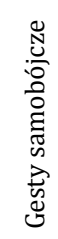 & 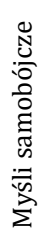 & 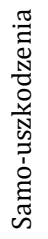 & 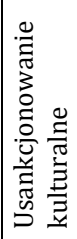 & 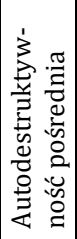 & 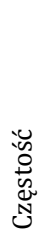 & $\begin{array}{l}\mathbb{\pi} \\
\mathbb{N} \\
0 \\
0\end{array}$ & 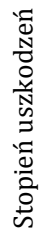 & $\begin{array}{l}3 \\
0 \\
0 \\
3 \\
0 \\
0\end{array}$ & 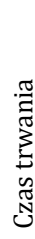 \\
\hline Alexian Brothers Assesment of Self Injury (ABASI) [23] & & & & & + & & + & + & + & & + & \\
\hline The Non-Suicidal Self-Injury Assessment Tool (NSSI-AT) [26] & & & & & + & & & + & + & + & + & + \\
\hline Self-Injury Trauma Scale (SITS) [25] & & & & & + & & & & + & + & & \\
\hline Motivational Assessment Scale (MAS) [34] & & & & & + & & & & & & + & \\
\hline Behawior Problems Inventory (BPI) [25] & & & & & + & & + & & & & & \\
\hline Overt Aggression Scale (OAS) [25] & & & & & + & & + & & & + & & \\
\hline Self-Injurious Thoughts and Behaviors Interview (SITB) [36] & + & + & + & + & + & & & & & & & \\
\hline Alexian Brothers Urge to Self-Injury Scale (ABUSI) [23] & & & & & + & & & + & & & & + \\
\hline Difficulties in Emotion Regulation Scale (DERS) [27] & & & & & & & & & & & + & \\
\hline The Suicide Behaviors Questionnaire - Rvised (SBQ-R) [29] & & & & + & & & & & & & & \\
\hline Suicide Assesment Checklist (SAC [38] & & & & & & & & & & & + & \\
\hline
\end{tabular}

Zakres problematyki związanej z NSSI ocenianej przy użyciu różnych dostępnych narzędzi badawczych, przedstawiono w dwóch uzupełniających się tabelach: tab. 1 autorstwa Kubiak [51] oraz tab. 2 przygotowanej przez autorów tego artykułu (zawierającą skale nie uwzględnione w tab.1).

\section{PODSUMOWANIE:}

Niesamobójcze samookaleczania się nie są zjawiskiem obserwowanym jedynie wśród pacjentów szpitali i poradni psychiatrycznych. W społeczeństwie coraz częściej można spotkać autoagresywne osoby nigdy nieleczone psychiatrycznie, które nie potrafią sobie poradzić w inny sposób z narastającym napięciem wewnętrznym. 0 skali zjawiska może świadczyć ustanowiony na 1 marca Światowy Dzień Świadomości Autoagresji [64]. Na wzrost liczby przypadków NSSI w społeczeństwie, z pewnością wpływ mają czynniki środowiskowe, choć nie tłumaczą one w pełni takiej skali problemu. Obserwuje się lawinowo narastający problem NSSI u młodych osób. Terapia tego typu zaburzeń jest kompleksowa, z uwzględnieniem dominujących przyczyn jego występowania. By móc skutecznie nieść pomoc, potrzebna jest wielowymiarowa ocena niesamobójczych samouszkodzeń. Każde z przedstawionych w tym artykule narzędzi dostarcza innych informacji o pacjencie, o jego zachowaniach, rodzaju smaookaleczenia się, umiejętności regulacji emocji itp. By móc kompleksowo ocenić NSSI i towarzyszące im zaburzenia konieczne jest użycie kompletu uzupełniających się skal, gdyż żadna z dostępnych skal nie obejmuje złożoności NSSI.

\section{Conflict of interest}

The authors have declared no conflict of interest.

\section{References:}

1. Linowski K., Wysocki I. Agresja, autoagresja w przemoc w życiu człowieka. Przyczyny, przejawy, przeciwdziałanie i resocjalizacja Radom 2012; 92

2. Suchańska A., Wycisk J. Samouszkodzenia. Istota, uwarunkowania, terapia Poznań: Wydawnictwo Naukowe Bogucki 2000

3. Klonsky ED Non-suicidal self-injury in United States adults: prevalence, sociodemographics, topography and functions. Psychol Med. 2011 Sep; 41(9):1981-6

4. Selby EA, Bender TW, Gordon KH, Nock MK, Joiner TE Jr Nonsuicidal self-injury (NSSI) disorder: a preliminary study. Personal Disord. 2012 Apr; 3(2):167-75

5. Laye-Gindhu A, Schonert-Reichl KA. Nonsuicidal self-harm among community adolescents: understanding the "whats" and "whys" of self-harm. J Youth Adolesc. 2005;34(5):447-457

6. Kulikowska A. Samouszkodzenia umiarkowane z perspektywy terapii uzależnień Małopolski Ośrodek Szkolenia Terapeutów Uzależnień (MOSTU); eseje uczestników 2010

7. Amerykańskie Towarzystwo Psychiatryczne Diagnostic and Statistical Manual of Mental Disorders Fifth Edition DSM-5 New School Library 2013; 461-480

8. Urban E. \& Partner Kryteria diagnostyczne z DSM-5 Wrocław 2015, wyd.

9. Światowa Organizacja Zdrowia Międzynarodowa Statystyczna Klasyfikacja Chorób i Problemów Zdrowotnych ICD-10 Rewizja dziesiąta; Centrum Systemów Informacyjnych Ochrony Zdrowia 2012; 207-256

10. Pużyński S., Wciórka J. Klasyfikacja zaburzeń psychicznych i zaburzeń zachowania w ICD-10 Uniwersyteckie Wydanie Medyczne „Vesalius” Instytut Psychiatrii i Neurologii KrakówWarszawa 2000 
11. Kochańska K. Zobacz, co sobie robię. O zjawisku samookaleczania się kobiet Rocznik Towarzystwa Literackiego imienia Adama Mickiewicza 2007 (42), 163-181

12. Babiker G., Arnold L. Autoagresja. Mowa zranionego ciała Gdańsk: GWP 2002

13. Bilikiewicz A. Psychiatria. Podręcznik dla studentów medycyny Wydawnictwo Lekarskie PZWL, Warszawa 2009, wydanie III, 323-340

14. Eckhardt A. Autoagresja Warszawa W.A. B. 1998

15. Miernik-Jaeschke M. Różnice między nastolatkami, którzy myślą o podjęciu samouszkodzeń, a tymi, którzy ich dokonują - badanie obserwacyjne mp.pl Psychiatria 2012

16. Radziwiłłowicz W., Sumiło A. Psychopatologia okresu dorastania wydawnictwo Impuls, Kraków 2006

17. Jaworska A. Leksykon resocjalizacji wydawnictwo Impuls, Kraków 2012

18. Favazza A. The Coming of Age of Self - Mutilation The Jurnal of Nervous and Mental Diseases Volume 1996; 186: 259 - 268

19. Rush J. A. Spiritual Tattoo: A Cultural History of Tattooing, Piercing, Scarification, Branding, and Implants North Atlantic Books U.S. 2005

20. Stanley B., Sher L., Wilson S., Ekman R., Huang Y., Mann JJ. Nonsuicidal Self-Injurious Behavior, Endogenous Opioids and Monoamine Neurotransmitters. Journal of affective disorders. 2010;124(1-2):134-140.

21. Victor S. E., Glenn C. R., Klonsky E. D. Is non-suicidal self-injury an "addiction"? A comparison of craving in substance use and nonsuicidal self-injury. Psychiatry research, 2012, 197.1: 73-77.

22. Symons, F. J., Thompson, A. and Rodriguez, M. C. Self-injurious behavior and the efficacy of naltrexone treatment: A quantitative synthesis. Ment. Retard. Dev. Disabil. Res. Rev., 10: 193-200, 2004

23. Washburn J.J., Potthoff L.M., Juzwin K.R., Styer D.M. Assessing DSM-5 nonsuicidal self-injury disorder in a clinical sample Psychol Assess 2015

24. Klonsky E. D., Glenn C. R. Assessing the functions of non-suicidal self-injury: Psychometric properties of the Inventory of Statements About Self-injury (ISAS). Journal of Psychopathology and Behavioral Assessment, 2009, 31.3: 215-219.

25. Rojahn J., Matson J. L., Lott D., Esbensen A. J., Smalls Y. The Behavior Problems Inventory: An Instrument for the Assessment of Self-Injury, Stereotypes Behavior and Aggression/Destruction in Individuals With Developmental Disabilities. Journal of Autism and Developmental Disorders, 2001, 31(6), 577-588

26. Sze Yiu, Wong C. A study of the reasons and functions of nonsuicidal self-injury (NSSI) among students in Hong Kong and United Kingdom Lingnan University, 5-4-2012

27. Gratz K. L., Roemer L. Multidimensional Assessment of Emotion Regulation and Dysregulation: Development, Factor Structure, and Initial Validation of the Difficulties in Emotion Regulation Scale Journal of Psychopathology and Behavioral Assessment, Vol. 26, No. 1, March 2004

28. Gratz, K. L. Measurement of deliberate selfharm: Preliminary data on the deliberate selfharm inventory. Journal of Psychopathology and Behavioral Assessment, 2001, 23(4), 253-263

29. Osman A., Bagge C. L., Gutierrez P.M., Konick L. C., Kopper B.A., Narrios F.X. The Suicidal Behaviors Questionnaire - Revised (SBQ-R): Validation With Clinical and Nonclinical Samples Assesment 2001, Volume 8, Number 4, 443-454

30. Samsone R. A., Wiederman M. W., Samsone L. A. The Self-Harm Inventory (SHI): development of a scale for identifying selfdestructive behaviors. Journal of Clinical Psychology 1998, 10, 193-203
31. Gutierrez P.M., Osman A., Barrios F. X., Kopper B. A. Development and initial validation of the Self-Harm Behavior Questionnaire. 2001 Journal of Personality Assessment, 77(3), 475-490

32. Cloutier P. F., Nixon M. K. The Ottawa Self-Injury Inventory: A preliminary evaluation Abstracts to the 12th International Congress European Society for Child and Adolescent Psychiatry. European Child \& Adolescent Psychiatry 2003, 12(Suppl. 1) 1-94.

33. Lloyd E. E., Kelley M. L., Hope T. Self-mutilation in a community sample to adolescents: Descriptive characteristics and provisional prevalence rates. Poster presented at the annual meeting of the Society for Behavioral Medicine, New Orleans, LA, 1997

34. Cleas L., Vandereycken W., Vertommen H. Clinical assessment of self-injurious behaviors: an overview of rating scales and selfreporting questionares. W: A. Columbus (red.) Advances In Psychology Reserch. New York: Nova Science Publishers, 183-209, 2005

35. Linehan M. M., Comtois K. A., Brown M. Z., Heard H. L., Wagner A. Suicide Attempt Self-Injury Interview (SASII): Development, Reliability, and Validity of a Scale to Assess Suicide Attempts and Intentional Self-Injury Psychological Assessment, American Psychological Association, 2006, Vol. 18, No. 3, 303-312

36. Nock M. K., Holmberg E. B., Photos V. I., Michel B. D. Self-Injurious Thoughts and Behaviors Interview: Development, Reliability, and Validity in an Adolescent Sample Psychological Assessment, American Psychological Association, 2007, Vol. 19, No. 3,309-317

37. Juzwin K. An Assessment Tool for Self-Injury: The Self-Injury SelfReport Inventory (SISRI). W J. Levitt, R. Sansone, L. Cohn (red.) Self-Harm Behavior and Eating Disorders New York: BrunnerRoutiedge 2004, 105-118

38. Rogers J., Lewis M., Subich L. (2002) Validity of the Suicide Assessment Cheklist in an Emergency Crisis Center. Journal of Counseling \& Development. 80, 493-502

39. Zetterqvist M. The DSM-5 diagnosis of nonsuicidal self-injury disorder: review of the empirical literature Child and Adolescent Psychiatry and Mental Health 2015

40. Glenn C. R., Klonsky E. D. One-year test-retest reliability of the Inventory of Statements about Self-Injury (ISAS). Assessment, 2011, 18.3: 375-378.

41. Klonsky E. D., May A. M., Glenn C. R. The relationship between nonsuicidal self-injury and attempted suicide: converging evidence from four samples. Journal of abnormal psychology, 2013, 122.1: 231.

42. Muehlenkamp JJ, Swenson LP, Batejan KL et all Emotional and Behavioral Effects of Participating in an Online Study of Nonsuicidal Self-Injury: An Experimental Analysis Clinical Psychological Science 2015

43. Demirci E., Non suicidal self-injury, emotional eating and insomnia after child sexual abuse: Are those symptoms related to emotion regulation? J Forensic Leg Med. 2017 Nov 7;53:17-21.

44. Whitlock J., Exner-Cortens D., Purington A. Assessment of nonsuicidal self-injury: Development and initial validation of the NonSuicidal Self-Injury-Assessment Tool (NSSI-AT) Psychological Assessment, Vol 26(3), Sep 2014, 935-946

45. Whitlock J., Purington A. Validity and Reliability of the Non-Suicidal Self-Injury Assessment Tool (NSSI-AT): Why Use the NSSI-AT Cornell Research Program on Self-Injurious Behavior in Adolescents and Young Adults, Cornell University College of Human Ecology 2011

46. Fliege, H., Kocaleventa, R. D., Waltera, O. B., Becka, S., Gratz, K. L., Gutierrez, P. M., et al. Three assessment tools for deliberate selfharm and suicide behavior: Evaluation and psychopathological correlates. Journal of Psychosomatic Research 2006, 61, 113-121 
47. Gratz, K. L. Risk factors for deliberate self-harm among female college students: The role and interaction of childhood maltreatment, emotional inexpressivity, and affect intensity/ reactivity. American Journal of Orthopsychiatry 2006, 76(2), 238-250.

48. Gratz, K. L. Targeting emotion dysregulation in the treatment of selfinjury. Journal of Clinical Psychology 2007, 63(11), 1091-1103

49. Gratz, K. L., \& Chapman, A. L. The role of emotional responding and childhood maltreatment in the development and maintenance of deliberate self-harm among male undergraduates. Psychology of Men and Masculinity 2007, 8(1), 1-14

50. Laurie M. Craigen Amanda C. Healey Cynthia T. Walley Rebekah Byrd and Jennifer Schuster Assessment and Self-Injury: Implications for Counselors SAGE 2010

51. Kubiak A. Dylematy związane z badaniem bezpośrednich zachowań autodestruktywnych w Nowoczesne metody badawcze w psychologii pod red. Paluchowski W. et spp. Poznań 2012, 49-65

52. Nixon M. K., Levesque C., Preyde M., Vanderkooy J., Cloutier P. F. The Ottawa Self-Injury Inventory: Evaluation of an assessment measure of nonsuicidal self-injury in an inpatient sample of adolescents Child and Adolescent Psychiatry and Mental Health, 2015

53. Martin J, Cloutier PF, Levesque C, Bureau JF, Lafontaine MF, Nixon MK. Psychol Assess. 2013 Sep; 25(3):1013-8. Epub 2013 May 6.

54. Martin J., Cloutier P. F., Nixon M. K. i inn. Psychometric Properties of the Functions and Addictive Features Scales of the Ottawa Self-Injury Inventory: A Preliminary Investigation Using a University Sample Psychological Assessment 2013, Vol.25, No. 3,1013-1018

55. Nock M. K., Prinstein M. J. A Functional Approach to the Assessment of Self-Mutilative Behavior Journal of Consulting and Clinical Psychology, American Psychological Association, 2004, Vol. 72, No. 5, 885-890

56. Iwata B.A., Pace G.M., Kissel R.C., Nau P.A., Farber J.M. THE SELFINJURY TRAUMA (SIT) SCALE: A Method For Quantifying Surface Tissue Damage Caused By Self-Injotius Behawior Journal of Applied Behawior Analysis 1990

57. Symonsa F.J., Harperd V.N., McGrathc P.J., Breauc L.M., Bodfish J.W. Evidence of increased non-verbal behavioral signs of pain in adults with neurodevelopmental disorders and chronic selfinjury Research in Developmental Disabilities 2009

58. Carminati GG, Gerber F, Darbellay B, Kosel MM, Deriaz N, Chabert J, Fathi M, Bertschy G, Ferrero F, Carminati F. Using venlafaxine to treat behavioral disorders in patients with autism spectrum disorder. Prog Neuropsychopharmacol Biol Psychiatry. 2016 Feb 4;65:85-95. doi: 10.1016/j.pnpbp.2015.09.002. Epub 2015 Sep 9.

59. Benedetti-Isaac JC, Torres-Zambrano M, Vargas-Toscano A, Perea-Castro E, Alcalá-Cerra G, Furlanetti LL, Reithmeier T, Tierney TS, Anastasopoulos C, Fonoff ET, Contreras Lopez WO. Seizure frequency reduction after posteromedial hypothalamus deep brain stimulation in drug-resistant epilepsy associated with intractable aggressive behavior. Epilepsia. 2015 Jul;56(7):115261. doi: 10.1111/epi.13025. Epub 2015 Jul 4.

60. Washburn J.J., Richardt S.L., Styer D.M. et all Psychotherapeutic approaches to non-suicidal self-injury in adolescents Child and Adolescent Psychiatry and Mental Health 2012

61. Muehlenkamp JJ, Swenson LP, Batejan KL et all Emotional and Behavioral Effects of Participating in an Online Study of Nonsu icidal Self-Injury: An Experimental Analysis Clinical Psychological Science 2015

62. Neumann A., Pol A. C. van Lier, Gratz KL, and Koot HM Multidimensional Assessment of Emotion Regulation Difficulties in Adolescents Using the Difficulties in Emotion Regulation Scale SAGE 2010

63. Somma A., Sharp C., Borroni S., Fossati A. Borderline personality disorder features, emotion dysregulation and non-suicidal self- injury: Preliminary findings in a sample of community-dwelling Italian adolescents Personal Ment Health 2016

64. SIAD: Self Injury Awareness Day: LifeSIGNS". Retrieved 6 January 2016

\section{Correspondence address}

Ewelina Drzał-Fiałkiewicz

I Klinika Psychiatrii, Psychoterapii i Wczesnej Interwencji

Ul. Głuska 1, 20-439 Lublin

Tel. 817487307

Otrzymano: 07.11.2016

Zrecenzowano: 29.11.2016

Przyjęto do druku:18.12.2017 